\title{
Budding Yeast Measurement
}

National Cancer Institute

\section{Source}

National Cancer Institute. Budding Yeast Measurement. NCI Thesaurus. Code C106504.

Examination of a biological specimen to detect the presence of any yeast cells that are in the budding phase of asexual reproduction. 